\title{
TRANSITIVIDADE E AUTO/REPRESENTAÇÃO EM UM DEBATE POLÍTICO
}

\author{
(Transitivity and self/representation in a political debate)
}

\author{
Sara Regina Scotta Cabral ${ }^{1}$ \\ (Universidade Federal de Santa Maria - UFSM)
}

\begin{abstract}
Debates in political campaigns are common discursive practices in electoral processes that lend themselves to semiotic and linguistics analysis. By choosing the second option, we intend to demonstrate how representation is built by two Brazilian presidential candidates. The debate, broadcasted on national television by the Brazilian TV - Globo - was later transcribed and published on g1.globo.com site. For analysis, we used the theoretical frame of Systemic Functional Linguistics (Halliday, 1994; Halliday; Matthiessen, 2004, 2014) regarding the transitivity system, especially processes and participants. The results point to different representations between the two candidates: while one is built, linguistically, as someone who has enough attributes to lead the nation, another is built as the candidate who believes in his ability to make changes.
\end{abstract}

Keywords: political discourse, systemic functional linguistics, transitivity, relational processes

\section{RESUMO}

Debates em campanhas políticas são práticas discursivas comuns em processos eleitorais que se prestam à análise tanto semiótica quanto linguística. Ao optarmos pela segunda possibilidade, pretendemos demonstrar como ocorre a representação de si e do outro, construída por dois candidatos à Presidência do Brasil. O debate, transmitido em cadeia nacional pela TV brasileira Globo -, foi posteriormente transcrito e disponibilizado no site g1.globo.com. Para análise, usou-se o aparato teórico da Linguística Sistêmico Funcional de Halliday (1994) e Halliday e Matthiessen (2004; 2014) no que se refere ao sistema de transitividade, especialmente processos e participantes. Os resultados apontam para representações diferentes entre os dois candidatos: enquanto um se constrói, linguisticamente, como alguém que possui atributos suficientes para dirigir a nação, outro se constrói como o candidato que acredita na sua capacidade de realizar mudanças.

Palavras-chave: discurso político, linguística sistêmico-funcional, transitividade, processos relacionais

\section{Introdução}

O discurso político, enquanto instância discursiva, apoia-se em estruturas e comportamentos linguísticos necessariamente ligados a estruturas argumentativas decisivas para a persuasão do eleitor. Por esse motivo, Charaudeau (2011) afirma que podemos, primariamente, pensar o ato político tanto como atividade verbal e como ação.

$\mathrm{O}$ ato político visto, como atividade verbal, é caracterizado pela alteridade, pela influência e pela regulação, conforme propõe Charaudeau (2011, p. 16). A alteridade supõe a

\footnotetext{
${ }^{1}$ Professora Adjunta do Departamento de Letras Vernáculas da Universidade Federal de Santa Maria. Docente e orientadora no Programa de Pós-Graduação em Letras - área de Estudos Linguísticos - na UFSM. Dedica-se à Linguística Aplicada, sobretudo, aos Estudos da Linguagem na perspectiva sistêmico-funcional.
} 
presença do outro e a nossa como sujeitos; a influência objetiva levar o outro a pensar, dizer ou agir segundo uma intenção. A regulação, por sua vez, ocorre quando o outro também possui um projeto de influência.

A ação política é o aspecto que determina a ordem social dos indivíduos para que possam conviver, mais ou menos harmoniosamente, em vista do bem comum. Tais aspectos pertinentes à política (linguagem e ação) entram numa relação de reciprocidade, na qual um não existe sem o outro, originando-se práticas sociais de cunho político. Como o discurso político constitui uma forma de prática social complexa, resultante da reciprocidade entre linguagem e ação, Charaudeau (2011) sugere que é necessário considerá-lo como ato de comunicação e como evento comunicativo, onde se materializam as formas retóricas para a adesão a ideias particulares com fins de acesso ao poder.

Por outro lado, nas palavras de Pinto (2006, p. 89), o discurso político "é, ao mesmo tempo, dinâmico, frágil e, facilmente, expõe sua condição provisória”. Para a referida estudiosa, uma das principais características do discurso político é a sua necessidade de sobreviver e impor a sua verdade para um grande público. Nessa perspectiva, Pinto (2006), De Souza (2011) e Charaudeau (2012) confirmam a característica persuasiva do discurso político. Registre-se, ainda, que Chilton e Schaffner (2002, p. 5), retomado por Souza (2011), ressaltam que política é "uma luta por poder entre duas partes, aquelas que procuram reclamar e manter poder e aquelas que procuram resistir a ele”. O espaço de discussão política se torna, pois, um espaço de persuasão, "no qual a instância política, jogando com argumentos da razão e da paixão, tenta fazer a instância cidadã aderir a sua ação", como bem observa Charaudeau (2011, p. 19).

O objetivo deste trabalho é demonstrar como ocorrem linguisticamente, no espaço de persuasão, as representações pessoais construídas por duas vozes oponentes - as de dois candidatos à Presidência do Brasil no ano de 2014. Para tal, escolheu-se o último debate dos presidenciáveis, transmitido em cadeia nacional pela TV brasileira - TV Globo -, o qual foi posteriormente transcrito e disponibilizado na internet. Para análise, usou-se o aparato teórico da Linguística Sistêmico Funcional de Halliday (1994) e Halliday e Matthiessen (2004; 2014) no que se refere ao sistema de transitividade. Para a operacionalização da tarefa, uma vez reunido o corpus, foi utilizado o programa computacional Word Smith 5.0 (SCOTT, 2008).

Este trabalho apresenta, inicialmente, considerações sobre a metafunção ideacional experiencial e o sistema de transitividade. Logo após, detalha a metodologia empregada na análise do corpus e, por fim, apresenta os resultados obtidos. 


\section{Metafunções da linguagem}

$\mathrm{Na}$ década de 60, o linguista britânico Michael Halliday fez uma proposição de funções da linguagem, tendo em vista o papel que ela exerce ao ser utilizada pelos falantes em suas experiências e trocas linguísticas. Essa orientação, "na continuação de uma tradição que tem os nomes de Bronislaw Malinowski (1884-1942) e de Karl Bühler (1879-1963) como referentes exponenciais" (GOUVEIA, 2009), toma função como sinônimo de uso.

Halliday opta por substituir o termo funções da linguagem por metafunções da linguagem $(1968,1973)^{2}$ e assim justifica sua escolha:

Por que este termo um tanto pesado "metafunção"? Poderíamos tê-lo chamado simplesmente de "funções", no entanto há uma longa tradição em se falar sobre as funções da linguagem em contextos em que "função" significa simplesmente propósito ou forma de usar a língua, o que não tem significado algum para a análise da linguagem em si (cf. Halliday \& Hasan, 1985: cap. 1; Martin, 1990). Mas a análise sistêmica mostra que essa funcionalidade é intrínseca à linguagem: isto é, toda a arquitetura da linguagem é disposta ao longo de linhas funcionais. A linguagem é como é por causa das funções com que ela evoluiu na espécie humana. O termo "metafunção" foi adotado para sugerir que a função é um componente integral de toda a teoria (HALLIDAY; MATTHIESSEN 2004, p. 30-31)

As metafunções nascem das condições contextuais em que os discursos acontecem, levando em conta a situação de comunicação - é o contexto de situação, do qual Hasan (1989) aponta três variáveis: campo (o que acontece), relações (com quem acontece) e modo (como acontece). Também concorre para a realização dos eventos de linguagem o contexto mais amplo (contexto de cultura) que abrange crenças, valores e práticas de uma comunidade. Ambas as forças - a da situação e a da cultura - influenciam as escolhas e os propósitos comunicativos dos usuários da linguagem, a qual "é usada como instrumento de ação, materializado nas escolhas linguísticas que cada falante precisa fazer, tendo de considerar sempre o conjunto de variáveis contextuais que condicionam a comunicação" (FUZER; CABRAL, 2014, p. 26).

Ao estabelecer que "os componentes fundamentais do significado na língua são os componentes funcionais" (NEVES, 1997, p. 62), Halliday delimita dois significados como principais, na língua, que se manifestam em sistemas linguísticos diferentes: os significados de representação do mundo (ligados à variável contextual campo) e aqueles de interação com o outro (ligados à variável relações). Um terceiro significado é agregado aos outros dois -

\footnotetext{
2 Segundo Neves (1997), os primeiros usos do termo "metafunções" ocorreram com as obras de Halliday denominadas Notes on Transitivity and Theme in English (Parte I, publicada em 1968, e Parte II, publicada em 1973) e Explorations in Functions of Language, de 1973.
} 
aquele que diz respeito à organização da mensagem (ligado à variável modo). São as metafunções ideacional, interpessoal e textual - ou os três significados intrínsecos da linguagem da perspectiva sistêmico-funcional, conforme a Figura 1, apresentada a seguir.

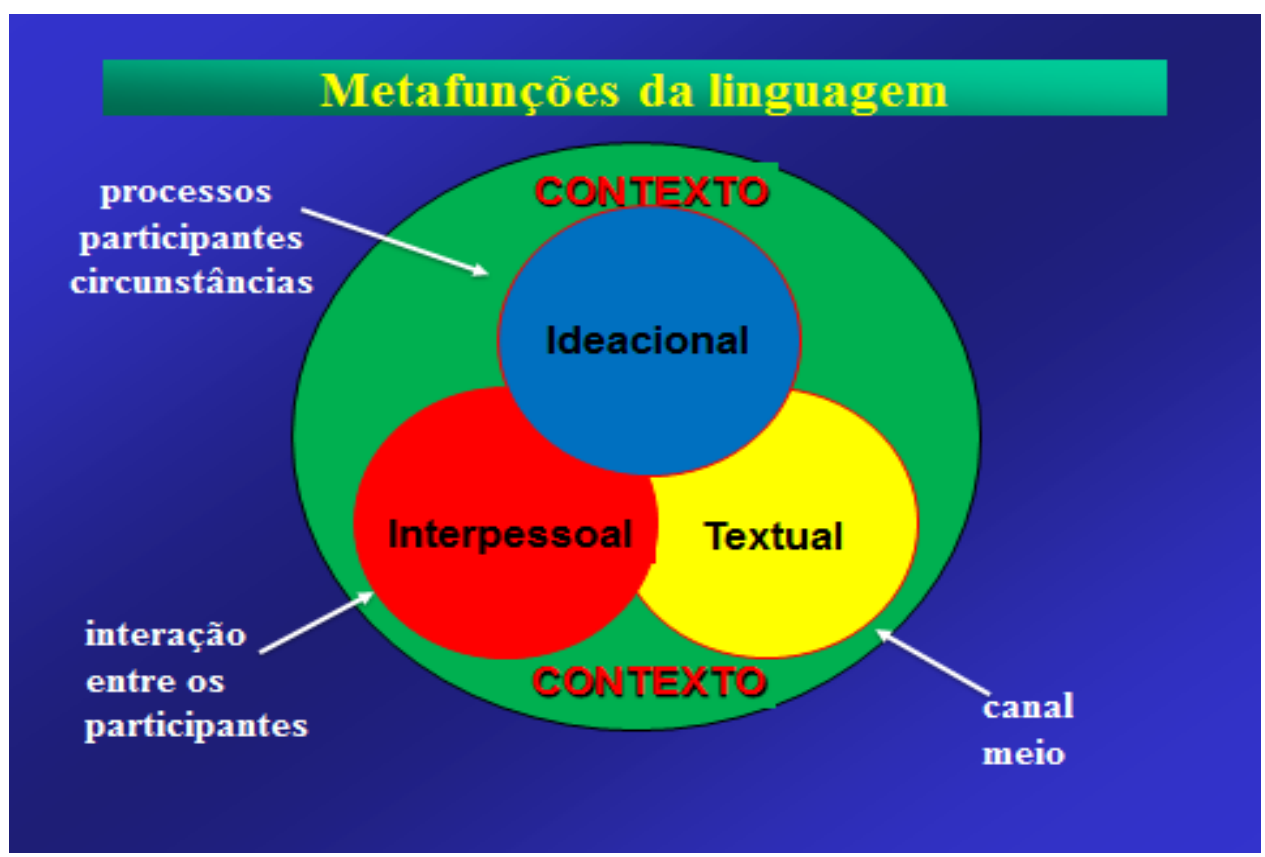

Figura 1: Metafunções da linguagem

Fonte: Adaptado de Halliday (1994)

A primeira tem por objetivo representar o mundo (metafunção ideacional); a segunda, ser um instrumento de interação (metafunção interpessoal); a terceira, organizar a informação (metafunção textual). Cada uma dessas metafunções, reunidas na Figura 1, realiza-se em torno de redes de escolhas mais ou menos independentes, que constituem o grande sistema linguístico. As três metafunções realizam-se concomitantemente, e sua separação só é realizada para fins didáticos.

A metafunção ideacional da linguagem constrói significados da experiência humana ao lançar mão de recursos léxico-gramaticais apropriados e disponíveis para uso. Os significados ideacionais apresentam dois componentes: um experiencial, que trabalha com o sistema de transitividade (objeto deste trabalho), e outro lógico, que trata das relações entre orações.

\begin{tabular}{|c|c|c|c|c|c|}
\hline 1 & Essa & será & uma grande prioridade & no nosso governo. & $\mathrm{AN}^{3}$ \\
\cline { 2 - 5 } & participante 1 & processo & participante 2 & circunstância & \\
\hline
\end{tabular}

\footnotetext{
${ }^{3}$ As abreviaturas AN e DR indicam, respectivamente, Aécio Neves e Dilma Rousseff.
} 


\begin{tabular}{|c|c|c|c|}
\hline 2 & || $\mid$ Moro há 15 anos $\|$ e o meu aluguel triplicou nos últimos quatro anos.|| & AN \\
\cline { 2 - 3 } & oração 1 & oração 2 & \\
\hline
\end{tabular}

Em (1), pode-se observar como, experiencialmente, foi construída a oração: o participante 1 liga-se ao participante 2 através de um processo relacional, acrescida de uma circunstância. Já em (2), a primeira oração é estendida pela segunda através de uma relação lógico-semântica de extensão por adição, marcada pelo conjuntivo "e". Na seção a seguir, apresenta-se o tratamento hallidayano para a transitividade da oração.

\section{Sistema de transitividade}

A linguagem propicia aos seres humanos a transformação de suas experiências em significado. Para que isso ocorra, o ponto de partida sempre é a experiência interna, aquela da consciência prototipicamente humana, que serve de referência para "interpretar a experiência externa" (HALLIDAY; MATTHIESSEN, 1999, p. 222), individual e/ou coletiva e representála em termos de sequências ${ }^{4}$, figuras ${ }^{5}$ e elementos ${ }^{6}$.

A oração, ou figura, exerce um papel central na linguagem, porque corporifica o princípio geral da construção da experiência - o princípio de que a realidade é feita de entidades, circunstâncias e processos. O sistema gramatical pelo qual uma figura é construída chama-se transitividade (HALLIDAY, 1994). O sistema de transitividade (Figura 2) configura os eventos como orações centradas em tipos de processos, os quais constituem tipos distintos de domínios da experiência (HALLIDAY; MATTHIESSEN, 2014).

\footnotetext{
${ }^{4}$ Sequência é um conjunto de figuras (orações) logicamente articuladas em expansão ou em projeção, formando um complexo oracional.

${ }^{5}$ Figura é o conjunto de elementos (processos, participantes e circunstâncias), que formam uma mesma oração.

${ }^{6}$ Elementos são os itens léxico-gramaticais que estruturam as orações: processos, participantes, circunstâncias, qualidades.
} 


\section{Transitividade}

\section{CAMPO}

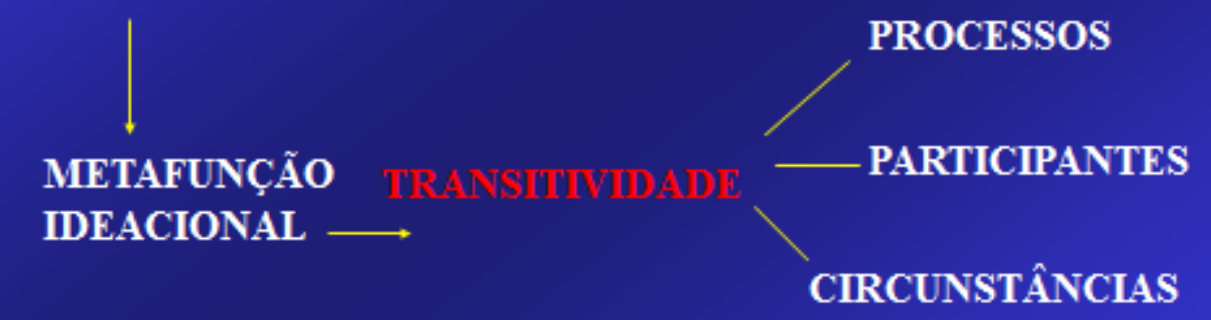

Figura 2: Transitividade

Fonte: Adaptado de Halliday (1994)

Os participantes do processo são as entidades envolvidas - pessoas ou coisas, seres animados ou inanimados. As circunstâncias referem-se às noções de tempo, modo, causa e lugar, dentre outros. A visão tríplice dos componentes da oração repousa, na verdade, na distinção gramatical das classes de palavras em verbos, nomes e advérbios.

Os processos, na perspectiva sistêmico-funcional, são usados com dois significados principais: a) para se referirem ao que está acontecendo no todo da oração; b) para se referir à parte da proposição encapsulada no sintagma verbal. Podem ser categorizados em três grandes grupos: material, mental e relacional. Além desses, três outros intermediários também são utilizados: verbal, comportamental e existencial (Figura 3). Em gramática funcional, cada tipo de processo envolve diferentes tipos de participantes. Os processos principais dentre os apresentados na Figura 3, constituem a tríade material, mental e relacional. 


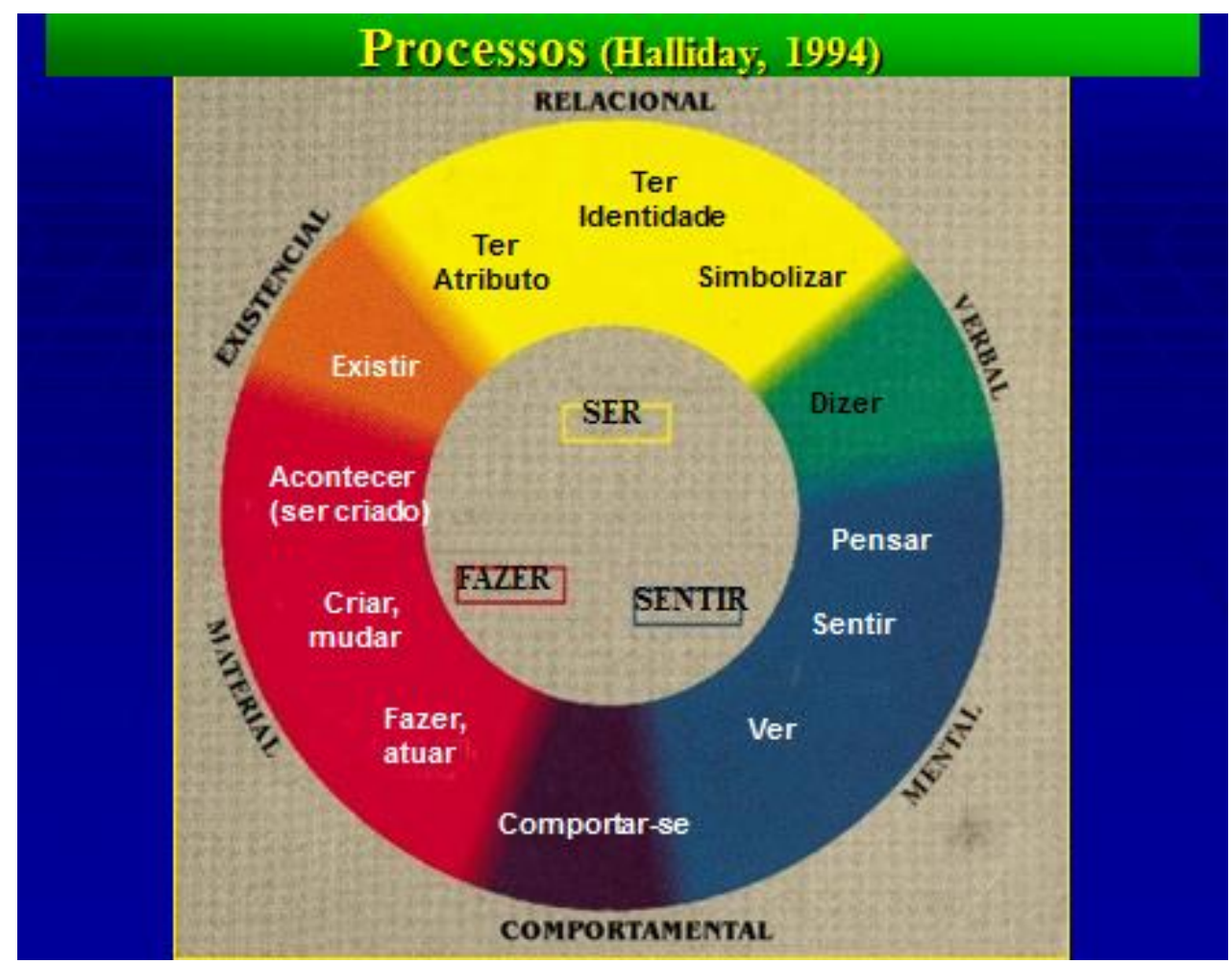

Figura 3: Processos

Fonte: Adaptado de Halliday (1994)

Os processos materiais, ou processos de "fazer", envolvem uma gama de ações e de acontecimentos do mundo real - a experiência externa do participante. Caracterizam-se por serem concretos: referem-se ao mundo físico, que pode ser percebido pelos sentidos humanos e que pode movimentar-se no espaço. Podem ser criativos, quando o participante é trazido à existência, ou transformativos, quando o processo provoca mudança no participante já existente. Em (3), 'tem feito' constitui um processo material criativo.

\begin{tabular}{|c|c|c|c|c|c|}
\hline 3 & O senhor & tem feito & $\begin{array}{c}\text { uma campanha extremamente } \\
\text { agressiva }\end{array}$ & a mim. & DR \\
\cline { 2 - 5 } & Ator & $\begin{array}{c}\text { Processo } \\
\text { material }\end{array}$ & Meta & Beneficiário & \\
\hline
\end{tabular}

Os processos materiais apresentam, no mínimo, um participante - é o Ator, representado por 'o senhor' em (3). A gramática clássica denominava esse termo 'sujeito lógico'. Pode haver também a Meta - "participante que recebe o impacto da ação" (FUZER; CABRAL, 2014: 50), como 'uma campanha extremamente agressiva' em (1) - e, algumas 
vezes, o Beneficiário, - o participante que é beneficiado/atingido pela ação, como 'a mim' também em (3).

Outros participantes dos processos materiais são o Escopo, entidade que não é afetada pelo processo, e o Atributo, que constitui uma característica atribuída a um dos participantes da oração. Nas orações materiais, o Atributo é usado "para construir o estado qualitativo resultante do Ator ou da Meta depois que o processo se completou" (HALLIDAY; MATTHIESSEN, 2004, p. 195).

Alguns processos envolvem fenômenos melhor descritos como estados de ânimo e eventos psicológicos. São os processos mentais, que representam a experiência interna do participante e são construídos através de verbos como "sentir", "pensar", “gostar", "querer” e outros. Uma diferença entre o processo material e o processo mental é que, no primeiro, todo participante é um ser - da realidade ou da imaginação humana. No segundo, o mental, tomam parte os fatos, construídos como participantes por projeção, ou seja, por discurso citado ou relatado, ou por ideias. Os fatos podem ser vistos, sentidos ou pensados, mas não podem "executar" alguma coisa, como no processo material.

Os processos mentais são experienciados pelo Agente do processo e participante consciente - o Experienciador (HALLIDAY, 1994; HALLIDAY; MATTHIESSEN, 2004; 2014). O participante atingido pelo processo é denominado Fenômeno - complemento do processo. O Experienciador pode ser qualquer entidade criada pela consciência humana: um ser, um objeto, uma instituição, uma substância. O Fenômeno, representado pelo conteúdo do sentido, refere-se ao que é sentido, pensado ou visto.

\begin{tabular}{|c|c|c|c|c|c|}
\hline 4 & $\ldots$.alguém] & olhar & com muita cautela & $\begin{array}{c}\text { essa questão do } \\
\text { porto. }\end{array}$ & DR \\
\cline { 2 - 5 } & Experienciador & $\begin{array}{c}\text { Processo } \\
\text { mental }\end{array}$ & Circunstância & Fenômeno & \\
\hline
\end{tabular}

Há quatro categorias de processos mentais: cognitivos (ex.: pensar, perceber, preocupar-se, pressupor), emotivos (ex.: entristecer, exultar, fascinar, gostar), desiderativos (ex.: ansiar, desejar, planejar, pretender) e perceptivos (ex.: notar, olhar, ouvir, perceber, ver). Fuzer e Cabral (2014), a partir de Halliday e Matthiessen (2004), traduziram uma listagem de verbos que servem como processos mentais e os adaptaram para a língua portuguesa.

Frequentemente, o Fenômeno pode estar representado por uma oração separada daquela que apresenta o Experienciador. Constitui o que Halliday (1994: 242) denomina 
oração projetada e representa uma idéia trazida à realidade por um processo mental, como ocorre com (5).

\begin{tabular}{|c|c|c|c|}
\hline 5 & $\|||$ Eu acredito & que esse acordo é possível.|\| & \multirow{2}{*}{ DR } \\
\cline { 2 - 3 } & Oração projetante & Oração projetada & \\
\cline { 2 - 3 } & $\alpha$ & $\beta^{7}$ & \\
\hline
\end{tabular}

Em (5), tem-se não uma oração simples, mas um complexo oracional. É um caso de projeção, em que a oração projetante apresenta um processo mental, e a oração projetada constitui não o Fenômeno, mas a Ideia.

Os processos que representam as categorias de (i) atribuição e (ii) identificação são denominados relacionais. Pertencem aos processos de 'ser' e lembram o conceito gramatical de cópula. São tipicamente realizados através do verbo 'ser' ou de qualquer outro similar e ainda os verbos 'ter', 'possuir' e 'pertencer'.

\begin{tabular}{|c|c|c|c|c|}
\hline 6 & $\ldots$ eu & sou & o candidato da mudança & AN \\
\cline { 2 - 4 } & Identificado & Processo relacional & Identificador & \\
\hline
\end{tabular}

\begin{tabular}{|c|c|c|c|c|}
\hline 7 & $\ldots$ é & vergonhosa & a posição do Brasil & DR \\
\cline { 2 - 4 } & Processo relacional & Atributo & Portador & \\
\hline
\end{tabular}

\begin{tabular}{|c|c|c|c|c|c|}
\hline 8 & ...eu & tenho & na minha vida & um orgulho & AN \\
\cline { 2 - 5 } & Possuidor & Processo relacional & Circunstância & Possuído & \\
\hline
\end{tabular}

Nas orações relacionais, há duas entidades de ser: $x$ (“eu”, “a posição do Brasil”, "eu”) é visto como sendo y (“o candidato da mudança", "vergonhosa", "um orgulho"), em que dois diferentes modos relacionais podem acontecer: (i) identificador (em 6) e (ii) atributivo (em 7 e 8). A principal diferença entre atribuição e identificação é a diferença entre (i) membros de uma classe (em 6) e (ii) simbolização (em 7 e 8). Assim, os participantes envolvidos nos processos relacionais são o Identificado e o Identificador, o Portador e o Atributo.

\footnotetext{
${ }^{7} \boldsymbol{\alpha}$ e $\boldsymbol{\beta}$ indicam uma relação hipotática entre as orações, em que $\alpha$ é a oração dominante e $\beta$ é a oração dependente.
} 
Além dos três tipos de processos apresentados, há outros três processos subsidiários que, para Halliday (1994), podem completar os processos básicos de (i) 'fazer/acontecer', (ii) 'sentir/pensar/perceber' e (iii) ‘ser'. São os processos de (iv) 'dizer', (v) 'comportar-se' e (vi) 'existir'.

Os processos de dizer são denominados por Halliday de processos verbais. Esta categoria inclui não só os diferentes modos de dizer (como em 9), mas também os traços semânticos adicionais que instrumentalizam o que se diz (como em 10)..

\begin{tabular}{|c|c|c|c|c|c|c|}
\hline 9 & $(\mathrm{Eu})$ & Já & disse & isso & anteriormente & DR \\
\cline { 2 - 5 } & Dizente & Circunstância & Processo verbal & Verbiagem & Circunstância & \\
\hline
\end{tabular}

\begin{tabular}{|c|c|c|c|c|}
\hline \multirow{2}{*}{10} & $\mathrm{Eu}$ & cumprimento & aos organizadores & DR \\
\cline { 2 - 3 } & Dizente & Processo verbal & Receptor & \\
\hline
\end{tabular}

Aquele que fala é denominado Dizente; aquilo que se fala é denominado Verbiagem. A Verbiagem é o escopo do dizer, em termos de categoria genérica (pergunta, anedota), categoria funcional (questão, declaração) ou categoria léxico-gramatical (palavra, frase). O Receptor, nem sempre presente, assemelha-se a um Beneficiário verbal, já que é a ele que se destina todo o processo.

Há ainda outro participante - o Alvo (Target na nomenclatura de HALLIDAY, 1994: 141). O Alvo é a entidade que é atingida pelo processo de dizer. É um participante periférico que não ocorre em discurso citado ou discurso relatado, apenas incidentalmente. São exemplos de verbos que aceitam Alvo: "descrever", "bajular", "insultar", "caluniar", “explicar”, "rezar”, “condenar”, “castigar”, “culpar” e outros.

Há inúmeros casos em que o conteúdo do dizer é representado por uma oração separada daquela que se constrói com o verbo de elocução e que projeta discurso citado ou discurso relatado.

\begin{tabular}{|c|c|c|c|c|c|}
\hline 11 & $\begin{array}{c}\text { Eu } \\
(\ldots)\end{array}$ & disse & $\begin{array}{c}\text { mais de uma } \\
\text { vez (...) }\end{array}$ & $\begin{array}{c}\text { Me honra muito essa comparação } \\
\text { com o pres. Fernando Henrique }\end{array}$ & AN \\
\cline { 2 - 5 } & Dizente & Proc. verbal & Circunstância & Oração projetada & \\
\hline
\end{tabular}




\begin{tabular}{|c|c|c|c|c|}
\hline 12 & ...todas as pessoas [[.]] & disseram & que melhoraram de vida. & DR \\
\cline { 2 - 4 } & Dizente & Processo verbal & Oração projetada & \\
\hline
\end{tabular}

Em (11), o conteúdo do dizer é textualizado com o uso do discurso direto (citação). Mesmo não havendo marcas como aspas, travessão - o que é mais comum em narrativas - é possível perceber a transcrição das palavras do candidato. Diferentemente em (12), a fala de "todas as pessoas" é projetada com o uso do discurso indireto na oração seguinte, constituindo um caso de relato.

O quinto tipo de processos é aquele que expressa comportamentos fisiológicos ou psicológicos de seres tipicamente humanos. O próprio Halliday os vê com características parcialmente materiais e parcialmente mentais. Segundo afirmam Bloor e Bloor (1995: 125), os processos comportamentais constituem uma 'área cinzenta' entre os dois processos mencionados.

O único participante, o Comportante, é um ser consciente, como o Experienciador, mas o processo se assemelha a 'fazer', não a 'sentir'. Podem ser considerados processos comportamentais os verbos que expressam (i) a forma do comportamento (observar, fitar, ouvir, ver), (ii) os processos de comportamento (tagarelar, resmungar), (iii) os processos fisiológicos que expressam estados de consciência (chorar, rir, sorrir, choramingar), (iv) os processos fisiológicos como 'transpirar', 'tossir', 'desmaiar', 'bocejar', 'dormir' e (v) as posturas corporais e os entretenimentos, tais como 'dançar', 'cantar', 'sentar' e outros. Em (13), "falar" constitui um processo comportamental próximo do verbal, porque representa a atividade em si realizada por "o senhor".

\begin{tabular}{|c|c|c|c|c|c|c|}
\hline \multirow{2}{*}{13} & ...o senhor & falou, & falou, & $\begin{array}{c}\text { e não } \\
\text { apresentou }\end{array}$ & $\begin{array}{c}\text { nada de } \\
\text { concreto }\end{array}$ & DR \\
\cline { 2 - 5 } & Comportante & Proc.comp & Proc.comportamental & Processo & Meta & \\
\hline \multicolumn{2}{|c|}{ Oração 1 } & \multicolumn{2}{|c|}{ Oração 2 } & \multicolumn{2}{|c|}{ Oração 3 } & \\
\hline
\end{tabular}

Os processos existenciais diferem dos relacionais porque, na oração existencial, há somente um participante: o Existente. São também processos de ser, mas não contam com o segundo elemento para estabelecer atributos ou identidades. Em (14) "nenhum brasileiro" é o Existente, e o processo existencial é expresso pelo verbo 'haver', o mais comum de todos. 


\begin{tabular}{|c|c|c|c|}
\hline 14 & não há & $\begin{array}{c}\text { nenhum brasileiro(...)[[que não tenha uma opinião } \\
\text { clara [[sobre o que aconteceu no mensalão ]] ]] }\end{array}$ & AN \\
\cline { 3 - 4 } & Processo existencial & \multicolumn{2}{|c|}{ Existente } \\
\hline
\end{tabular}

Em português falado, é comum usar-se 'ter' com sentido de 'existir', o que pode ser considerado funcionalmente como processo existencial, como demonstra (15).

\begin{tabular}{|c|c|c|c|c|}
\hline 15 & Candidato, & não tem & $\begin{array}{c}\text { Ministério do Desenvolvimento } \\
\text { Econômico... }\end{array}$ & DR \\
\cline { 2 - 4 } & ----- & Proc. existencial $^{8}$ & Existente & \\
\hline
\end{tabular}

Os verbos 'existir', 'ressurgir', 'ocorrer', 'acontecer', 'seguir', 'emergir' exercem o mesmo papel. Pesquisa realizada por Lima (2013) apresenta achados importantes sobre os processos existenciais empregados em reportagens de capa da revista Superinteressante.

Além de processos e participantes, a transitividade também se realiza com circunstâncias, terceiro elemento componente de uma figura. "Enquanto toda oração tem, pelo menos, um participante, somente certas orações são circunstancialmente acrescidas. No texto, em geral, o número médio de circunstâncias por orações é aproximadamente 0,45 , mas há uma diferença considerável entre orações que pertence a diferentes tipos de processos" (HALLIDAY; MATTHIESSEN, 2014, p. 221).

As circunstâncias têm por função "alargar" o centro da oração, constituído por processo e participante(s), ao introduzirem significados de temporalidade, espacialidade, causalidade, finalidade, modo, extensão e outros. Enquanto processos são representados linguisticamente por verbos e participantes por grupos nominais ou adjetivais, as circunstâncias são representadas por advérbios ou grupos adverbiais. É o caso de (16), em que se observa a presença de circunstâncias de modo, e de (17), circunstancializada por intensidade e modo.

\begin{tabular}{|c|c|c|c|c|}
\hline \multirow{2}{*}{16} & $(\mathrm{eu})$ & governo & sistemática e diuturnamente ... & DR \\
\cline { 2 - 5 } & Participante & Processo & Circunstância & \\
\hline
\end{tabular}

\footnotetext{
8 Em (15), "não" é marcador de polaridade, e "candidato" é vocativo. Como ambos são indicadores da metafunção interpessoal, não aparecem categorizados neste artigo. 


\begin{tabular}{|c|c|c|c|c|c|}
\hline 17 & $\ldots$ a senhora & sabe & muito bem & que nós tivemos... & AN \\
\cline { 2 - 5 } & Participante & Processo & Circunstâncias & Oração projetada & \\
\hline
\end{tabular}

$\mathrm{Na}$ seção a seguir, explicita-se o percurso metodológico realizado na análise da transitividade presente em um corpus constituído por um debate político no ano de 2014.

\section{Percurso metodológico}

No início deste artigo, apresentou-se a proposta de verificar como se realiza o sistema de transitividade e a representação construída por dois candidatos ao maior cargo político do Brasil. A fim de que a tarefa chegasse a termo, inicialmente foi feita a coleta do corpus, constituído do último debate que antecedeu o segundo turno das eleições presidenciais no Brasil em 2014. Transmitido em cadeia nacional pela TV Globo, posteriormente foi transcrito para o G1, portal de notícias brasileiro mantido pela Globo.com e sob orientação da Central Globo de Jornalismo. ${ }^{9}$

O debate aconteceu no dia 24 de outubro de 2014, sexta-feira, dois dias antes do segundo turno das eleições presidenciais. Iniciou às $22 \mathrm{~h} 11 \mathrm{~min}$ e teve a duração de $1 \mathrm{~h} 50 \mathrm{~min}$. Participaram o jornalista William Bonner, mediador, Dilma Rousseff (PT) e Aécio Neves (PSDB), ambos candidatos, eleitores indecisos selecionados pelo Instituto Ibope, além de uma plateia de convidados, estes sem direito a manifestação.

A sessão foi planejada para ocorrer em quatro blocos, cada um com tempo cronometrado. No primeiro e no terceiro, os candidatos fizeram três perguntas um ao outro sobre diversos temas e puderam utilizar meio minuto para pergunta, um minuto e meio para resposta, 50 segundos para a réplica e 50 segundos para a tréplica.

No segundo e no quarto blocos, as perguntas foram formuladas diretamente aos candidatos por eleitores indecisos, cujas questões, previamente enviadas, foram escolhidas pela produção da TV Globo. Cada pergunta ao candidato de sua preferência poderia durar 30 segundos, e a resposta, um minuto e meio, além de 50 segundos para que o adversário fizesse a réplica e 50 segundos para a tréplica. Em cada bloco, quatro perguntas foram formuladas pelos eleitores indecisos, totalizando oito até o final. Para encerrar o bloco 4, o mediador abriu espaço para a manifestação individual de cada um dos presidenciáveis.

\footnotetext{
9 A transcrição está disponível em http://g1.globo.com/politica/eleicoes/2014/transcricao-debate-presidencial-2turno.html (Confrontos, 2014).
} 
Uma vez apresentado o contexto de situação, passa-se a descrever as etapas de análise do debate. Para garantir a fidedignidade dos dados, foi utilizado o programa Word Smith Tools 5.0 (SCOTT, 2008). Aplicada a ferramenta WordList, foi possível fazer as estatísticas referentes ao texto. Os dados obtidos são:

Quadro 1: Quantitativo do corpus

\begin{tabular}{|l|c|}
\hline Número total de palavras & 12.063 \\
\hline Número de tokens utilizados na Word List & 11.900 \\
\hline Número de types & 2.291 \\
\hline TTR & 19.5 \\
\hline
\end{tabular}

Posteriormente, o corpus foi parcelado em dois subcorpora: o das falas de DR e o das falas de AN. O parcelamento teve por finalidade agrupar, em torno de cada candidato, as orações que havia proferido durante o debate. Os resultados obtidos nesta fase constam no Quadro 2.

Quadro 2: Quantitativo dos dois subcorpora

\begin{tabular}{|l|c|c|}
\hline & DR & AN \\
\hline Número total de palavras & 5.506 & 7.135 \\
\hline Número de tokens utilizados na Word List & 5.400 & 7.036 \\
\hline Número de types & 1.310 & 1.717 \\
\hline TTR & 24,26 & 24,40 \\
\hline
\end{tabular}

A seguir, foi feita a Lista de Palavras de cada um dos subcorpus, a fim de se verificar que elementos linguísticos foram mais frequentemente usados pelos dois candidatos. Como os processos e os participantes são considerados o centro da figura, foram buscados aqueles mais frequentes nos subcorpora, até a palavra de número 50, critério estabelecido aleatoriamente, tendo em vista um recorte necessário para análise.

Os resultados desta etapa mostraram, na sequência, que as seguintes palavras são as mais frequentes nas falas de DR: "eu, candidato, nós, senhor, vocês, muito, meu, tenho, pessoas, política, dizer”. Por outro lado, nas manifestações de Aécio, foram encontradas as seguintes palavras como frequentes: “candidata, governo, eu, nós, Brasil, seu, senhora, muito, hoje, brasileiros, são, meu, tem, pessoas, fazer". 
A partir da seleção de processos e participantes mais frequentes, foi possível encontrar termos-chave, através dos quais se chegou às representações que os dois debatedores fizeram de si e do opositor durante o evento. Quatro termos-chave orientaram a análise: (1) "eu”, (2) "meu governo" (3) "seu governo", e (4) "o senhor/a senhora" Delimitados os termos-chave para a busca, passou-se, a partir daí, a utilizar a ferramenta Concordancer, de modo a localizar os patterns referentes a esses termos nos subcorpora e investigar o contexto linguístico onde se encontram as ocorrências.

Na próxima seção faz-se a exposição dos achados e tecem-se algumas considerações acerca do sistema de transitividade e das representações presentes no corpus.

\section{Representação de si e do outro}

Com o uso do aplicativo Concordancer do Programa WordSmith Tools (Scott, 2008), é possível localizar palavras ou grupos de palavras em corpora previamente organizados e chegar ao contexto onde se realizam as ocorrências desejadas. No caso específico deste trabalho, quatro termos-chave foram obtidos para a investigação da transitividade no debate selecionado: (1) “eu”, (2) “meu governo” (3) "seu governo“ e (4) o senhor/a senhora”. Tendo em vista esse achado, passa-se à descrição, análise e interpretação de cada um deles.

\section{a) "Eu"}

Uma vez buscados nos subcorpora as ocorrências de "eu", foram percebidas algumas diferenças, sob o ponto de vista linguístico, no que concerne à autorrepresentação que os candidatos fazem de si.

$\mathrm{Na}$ fala de DR, seis patterns ${ }^{10}$ diferentes foram encontrados. São eles: "eu tenho", “eu queria/eu quero", “eu não", “eu vou”, "eu acho" e "eu acredito”. De relance, é possível perceber que DR faz uso de processo relacional possessivo, processo mental desiderativo, processo material, processos mentais cognitivos. Pode-se afirmar, então, que ela começa a se construir como alguém que possui, que deseja, que nega, que pensa, que faz.

Em "eu tenho", além do participante "eu", DR mostra deter a posse de bens imateriais, como "orgulho, certeza, compromisso, condições, respeito pela liberdade de imprensa".

\footnotetext{
${ }^{10}$ Pattern, em Word Smith, designa qualquer porção de linguagem que apresente partes repetidas.
} 
18 Eu tenho certeza que nós iremos construir mais ainda se eleito....

19 Eu tenho orgulho de ter dado inteira autonomia, que não era dada nos governos anteriores, porque nomeavam filiados de partidos para dirigir a Polícia Federal.

Ao explicitar a posse de bens imateriais, intangíveis (como em 18 e 19), DR busca demonstrar suas características de nobreza de caráter, de cumprimento da palavra, do preparo para governar e da tolerância com a liberdade de expressão.

O segundo pattern - "eu queria/eu quero" - faz-se acompanhar de projeções, todas em discurso indireto. Além do Experienciador "eu", o processo mental desiderativo requer, em vez de um Fenômeno, uma complexificação em favor do discurso relatado. As orações projetadas são "dizer, te dizer, falar, voltar à questão do emprego, que o senhor tivesse zelo", “deixar claro", "que digam" e "reiterar". Prevalece a combinação com o processo verbal “dizer”, caracterizado como processo neutro por Halliday e Matthiessen (2004; 2014).

20 Eu queria dizer uma coisa para você. Eu vi numa reportagem da GloboNews que todas as pessoas que participaram do debate de 2010 disseram que melhoraram de vida.

21 Eu quero reiterar que vocês quebraram os bancos públicos do Brasil. Quero DR reiterar que a Caixa, que era um dos maiores bancos do país, vocês minguaram a Caixa.

O exemplo (20) apresenta uma estratégia discursiva que é a predição: “dizer uma coisa", que é logo a seguir explicitada através de uma citação. ("Eu vi...). Ao mesmo tempo, o verbo "querer", que é usado no tempo passado, contém aspecto de presente. Essa mudança para o passado imperfeito funciona como uma metáfora interpessoal no momento da fala. Outra estratégia utilizada por DR é a repetição de verbos, como se pode ver em (21), o que contribui para enfatizar o que está sendo relatado e buscar a atenção para a gravidade do ocorrido.

O pattern "eu não", o terceiro dentre os achados, caracterizado como de polaridade negativa, está acompanhado de processos mentais cognitivos. Foram encontrados no subcorpus exemplos com "acredito", "entendo", "sei" e "acho". 
22 Me desculpe, candidato, eu não acredito, sabe por quê?

DR

23 Muito boa a sua pergunta. Eu não acho que o Brasil não está gerando $\quad$ DR emprego.

Ao privilegiar o uso de processos mentais com polaridade negativa, DR coloca-se como alguém firme em suas convicções: não acredita, não entende (= não pensa assim), não sabe, não acha. A negação, aqui, não funciona como falta de capacidade, mas como um recurso para demarcar suas opiniões. Para isso, veja-se o exemplo 22, em que, após a negação, busca apresentar as razões pessoais para a falta de crença.

Em (23), ocorre o fenômeno da dupla negação, o que resulta em uma afirmativa: "Eu não acho que o Brasil não está gerando" significa que "pensa que o Brasil está realmente gerando emprego".

O quarto pattern está caracterizado pela coloquialidade. DR prefere reunir "eu vou" com "investigar", "dar prioridade", "dar atenção", "condenar", "concordar" e "reportar", quando poderia ter empregado "investigarei”, "priorizarei”, “darei atenção”, condenarei”, "concordarei" e "reportarei”, formas características de linguagem mais elaborada. Como o objetivo da candidata é convencer seus eleitores de que ela é a melhor opção, DR busca aproximar-se deles, adotando formas verbais mais populares, como demonstram (24 e 25). .

24 Eu vou dar absoluta prioridade a esgotamento sanitário.

DR

25 Candidato, eu vou reportar primeiro ao Banco do Brasil. Vocês deixaram o Banco do Brasil com uma grave dívida.

Com "eu vou", DR mostra-se assertiva e determinada a agir (investigar, dar prioridade), a executar ações mentais (dar atenção, concordar, condenar) e a se manifestar verbalmente (reportar),

Outros dois combinações são bastante empregados por DR. São eles “eu acho" e "eu acredito", ambos constituídos por processos mentais (achar, acreditar).

26 Candidato, eu acho que o senhor não tem interesse na reforma política, porque a única coisa que o senhor fala é sobre reeleição. 
\begin{tabular}{|l|ll|l|l|}
\hline 27 & ... eu acho que nós temos de tratar a questão da droga com duas ações, & DR
\end{tabular} tratamento e prevenção.

28 Agora, eu acredito que a questão da reforma política não é a reeleição, não.

DR

29 Eu tenho assim um grande compromisso com creche e pré-escola. Por que eu acredito que creche e pré-escola é o futuro do país.

A construção "eu acho" significa "eu penso" e aproxima-se de "eu acredito". Ambas fazem parte de complexos oracionais cuja relação é de projeção, todas elas com relatos. Os processos mentais (achar, acreditar) que constituem as orações projetantes são seguidas, na maioria, por orações projetadas em que há processos relacionais (26, 27, 28 e 29). Há somente uma ocorrência de processo verbal em oração projetada (30).

\begin{tabular}{|l|l|l|}
30 & Agora candidato, eu acredito que o senhor cita duas revistas, candidato, que & DR
\end{tabular} nós sabemos para quem fazem campanha.

Fazer uso de orações projetantes como "eu acho" e "eu acredito" também constituem maneiras de modalizar o discurso, tornando-o menos categórico. Note-se que apenas nessas ocorrências DR se mostra menos comprometida com suas afirmações. Prova é que o Adjunto modal correspondente "talvez" não ocorre nem uma vez no subcorpus das falas de DR.

Por outro lado, o candidato AN é mais econômico no número de patterns que realiza em suas declarações. Somente três são recorrentes: “eu tenho", "eu não" e "eu quero".

No primeiro, "eu tenho", AN simboliza uma relação de posse com bens imateriais como "orgulho" e "convicção", um bem material (um projeto) e uma cronologia (43 anos).

31 E eu tenho absoluta convicção, com a clareza das nossas propostas, com respeito às regras, com respeito às agências reguladoras, com uma política fiscal transparente, nós vamos gerar novos empregos para gente qualificada como você.

32 Hoje os estados precisam fazer gestão política, quase que pessoal, junto à União para garantir algum recurso do Fundo Nacional de Segurança ou mesmo do Fundo Penitenciário. Menos de 40\% desses fundos foi aplicado ao longo dos últimos três anos de governo. Eu tenho um projeto no Congresso Nacional como senador, ... 
Como Possuidor de "absoluta convicção" (31), AN constrói-se como alguém que tem certeza de que os objetivos de seu partido (gerar novos empregos) poderão ser alcançados se ele se tornar Presidente. Em (32), contrapõe a pequena aplicação de recursos do Fundo Nacional de Segurança e do Fundo Penitenciário a projeto que tem no Congresso Nacional, demonstrando, assim, a sua percepção antecipada de um problema que algumas pessoas desconhecem. Ao informar que "menos de 40\% dos recursos foi aplicado" no governo de DR, mostra-se também como conhecedor do tema em âmbito administrativo.

A construção “eu não" conjuga-se com processos relacionais, materiais e mentais.

33 Eu não sou hoje mais o candidato de um partido político, eu sou o candidato da mudança, essa mudança que você e sua família querem ver no país ...$$
\text { mudanç, essa mudança que vocé e sua faníla querem ver no pais ... }
$$

34 Elizabeth, eu não vou terceirizar responsabilidades. AN
35 Vamos voltar a ele até porque é preciso que os brasileiros que nos assistem $\mathrm{AN}$ saibam que a senhora, nos últimos debates, reafirmou que a inflação no Brasil está sob controle. Eu não acredito nisso, candidata.

Em (33), AN nega sua identificação como candidato de um partido determinado e não se coloca, desse modo, como parte de uma instituição. Vai mais além e declara-se como aquele que fará mudanças no Brasil, caso seja eleito. Para isso, emprega o processo relacional identificador "ser" acompanhado do Identificador "candidato", o que lhe proporciona uma identidade única, descolada de ideologias partidárias. As negações presentes em (34) e (35) referem-se a um processo material (terceirizar) e um processo mental (acredito).

O terceiro pattern encontrado nas falas de AN é "eu quero", em que o processo mental desiderativo acompanha "criar", “dizer", “tranquilizar" e "rever".

\begin{tabular}{|l|l|l|l|}
\hline 35 & E eu quero que, eu quero criar no Brasil inteiro o Poupança Jovem, que & AN
\end{tabular} também é um recurso que é depositado na conta dos alunos do ensino médio, que só pode ser sacado ao final do curso para que ele tenha um estímulo a mais para concluir a sua formação.

$36 \quad$ O que eu quero dizer é que os nossos compromissos, eles não mudam às vésperas das eleições. Nós vamos construir uma rede de proteção aos idosos hoje que passa pelo fator previdenciário revisto, portanto por um outro instrumento que não puna tanto como vem punindo os aposentados o fator previdenciário. 
37 Eu quero tranquilizar a todos os brasileiros e brasileiras porque nós não vamos apenas manter o Minha Casa, Minha Vida, nós vamos aprimorá-lo.

Pelos achados no subcorpus, pode-se afirmar que os desejos do candidato AN situamse no campo da materialidade criativa, em que a Meta é a criação de uma conta poupança para estudantes; da troca linguística que reitera os compromissos assumidos; das atividades mentais emotivas - a tranquilidade por não perder o Programa Minha Casa, Minha Vida.

\section{b) "Meu governo"}

Uma segunda forma de autorrepresentação é a escolha pelo uso de "meu governo". DR descreve seu governo como aquele que "não atrasa", "não esconde nada", "tem feito um imenso esforço", "prevê aumento de salários", faz a Polícia Federal investigar e atribui 24 bilhões ao Pronaf (Programa Nacional de Fortalecimento da Agricultura Familiar).

38 Eu tenho orgulho de ter dado inteira autonomia, que não era dada nos governos anteriores, porque nomeavam filiados de partidos para dirigir a Polícia Federal. A Polícia Federal no meu governo investiga.

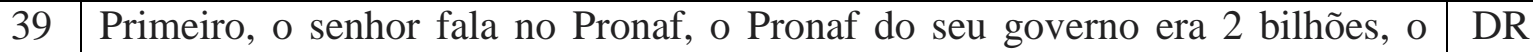
Pronaf do meu governo é 24 bilhões, há uma diferença, candidato, expressiva.

Prevalecem as combinações com processos materiais (atrasar, esconder, investigar), cujas Metas são "salários", "nada”), mas também há a presença de relacionais (ser, ter), em que o Portador "meu governo" tem os Atributos "24 bilhões" (38) e "aumento".

AN constrói diferentemente a imagem de seu governo, para o qual estabelece metas a serem atingidas: fortalecimento das Associações de Pais e Amigos dos Excepcionais, definição de investimentos de logística, apoio à qualificação e à remuneração dos professores, dentre outras.

\begin{tabular}{|l|l|l|}
\hline 40 & $\begin{array}{l}\text { Assumi com eles um compromisso, no nosso governo as Apaes serão } \\
\text { fortalecidas, diferente do seu governo que tentou extingui-las. E esses repasses } \\
\text { da garantia das transferências nesses recursos será prioridade absoluta no meu } \\
\text { governo. Pode faltar para outras, coisas, para essa não faltará. }\end{array}$ & \\
\hline
\end{tabular} 
41 O meu governo vai apoiar aqueles municípios e estados que remuneram pior os seus professores, que têm dificuldades financeiras de dar um salário melhor e uma qualificação melhor aos seus professores. Nós vamos revolucionar a educação no Brasil.

$\mathrm{Na}$ caracterização de seu governo, AN emprega principalmente processos materiais que indicam suas ações futuras - fortalecer, apoiar, cuidar -, cujos Beneficiários são as Apaes, os jovens, os bancos e os professores, a exemplo de (40) e (41).

\section{c) "Seu governo"}

Além das representações de si mesmos, o texto do debate apresenta representações que a candidata DR faz metonimicamente de seu opositor. O grupo "seu governo" é utilizado para acusar o governo do PSDB, anterior à entrada do PT na Presidência. O processo material "repassar" apresenta como Meta "o que nós repassamos" (42). O único processo relacional identificador (ser) tem como Identificado "2 bilhões" (43).

\begin{tabular}{|c|l|c|}
\hline 42 & $\begin{array}{l}\text { O seu governo candidato, eu tenho certeza, os seus governos, tanto do PSDB } \\
\text { como em Minas Gerais, vocês jamais repassaram para as Apaes o que nós } \\
\text { repassamos em todo meu período de governo: } \mathrm{R} \$ 5,9 \text { milhões. }\end{array}$ & \\
\hline
\end{tabular}

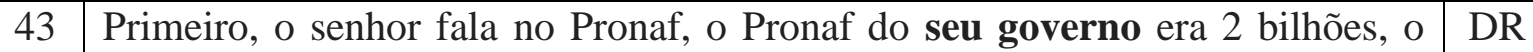
Pronaf do meu governo é 24 bilhões, há uma diferença, candidato, expressiva.

Há um único caso em que, nas falas de DR, "seu governo" faz parte de uma circunstância temporal (“durante o seu governo"). É o caso de (44), em que "a estratégia” é o Beneficiário da ação do "engavetador para o caso de impunidade" (Ator).

Também em (44) ocorre o caso em que um processo material (“deu") tem, junto de si, um Atributo ("certo").

44 Então, candidato, a estratégia do engavetador para o caso da impunidade durante o seu governo deu certo.

Quanto a AN, não foram encontradas ocorrências de "seu governo" durante o debate. O candidato preocupou-se mais em apresentar seus projetos, perspectivas de gestão, mudanças vistas por ele como necessárias e comprovar que ele seria a melhor opção. 


\section{d) "O senhor"/ "a senhora"}

Outro modo de construir representações do adversário está no emprego do tratamento "o senhor" e "a senhora". DR emprega frequentemente a denominação "o senhor" (48 vezes), fazendo-a acompanhar processos materiais, mentais, relacionais e verbais, para atacar o opositor e tentar destruir seus argumentos. Algumas ocorrências são:

45 Eu acreditei, candidato, que o senhor investia em saúde e educação, até ler um parecer do TCU em que fica claro que o senhor não cumpriu o mínimo constitucional, nem em saúde, nem em educação.

46 Candidato, o senhor precisa estudar mais, sabe, candidato, processos $\mathrm{DR}$ arquivados, processos encerrados. E vocês arquivaram e encerraram, e deixaram, também, passar o tempo para o julgamento.

47 Eu acho que o senhor está mal informado, porque quem deixou o país com uma inflação maior do que recebeu foi o governo tucano do Fernando Henrique.

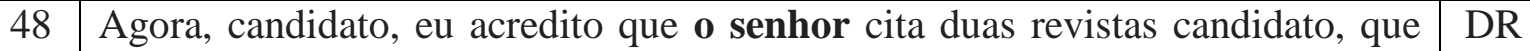
nós sabemos para quem fazem campanha.

49 Agora o senhor vem aqui e quer que as pessoas acreditem que vocês vão manter o subsídio. Eu não acredito nisso, candidato. Eu não acredito nisso, porque vocês sistematicamente, ao longo de todo o governo Fernando Henrique, foram contra o subsídio.

Os participantes das orações apresentadas também contribuem para a postura adotada por DR. Em (45), a Meta “o mínimo constitucional” coloca AN em uma posição de incompetência, já que não conseguiu realizar, na saúde e na educação, o mínimo previsto em lei e que se espera de um governante. O excerto (46) o intensificador "mais" reforça o desconhecimento de AN em relação a procedimentos jurídicos, assim como (47), onde o tema é “inflação". Nas passagens (48) e (49), a Verbiagem (duas revistas) e a projeção a partir de um processo mental (quer), DR demonstra seu desprezo pelas duas revistas (Veja). Note-se que frequentemente DR usa o tratamento "você/vocês" para se dirigir ora para AN ora para o PSDB.

Por sua vez, AN também emprega o tratamento, desta vez "a senhora". Dentre as 41 ocorrências do subcorpus, estão processos materiais, relacionais, mentais e verbais. 
50 A "Folha de São Paulo" publicou há poucos dias que numa sexta-feira, dos seus 39 ministérios apenas 15 ministros estavam trabalhando, e que a senhora ao longo dos últimos 35 dias, segundo o jornal de hoje, foi duas vezes ao Palácio do Planalto. Quem está governando o Brasil?

51 A senhora será a primeira presidente da República pós-plano real que deixará o país com uma inflação maior do que aquela que recebeu.

52 A senhora se orgulha, candidata, de uma campanha nesse nível?

53 Se a senhora quer falar com o mensalão mineiro o chamado mensalão mineiro, vamos aguardar que ele seja julgado, mas a senhora agora comete um grave, talvez até uma...

54 E o tema que a senhora traz é um tema que merece aqui uma reflexão. Bancos públicos serão fortalecidos, não serão aparelhados no meu governo, candidata. Em 2003, o Banco do Brasil tinha três diretorias, entre presidência, vicepresidência e diretorias.

No exemplo (50), o processo "ir" é formado por um verbo intransitivo, caso em que não há Meta. Em (51), AN usa o Identificador "primeira presidente da República pós-plano real", dando destaque ao fato de DR ser a responsável pelo descontrole da inflação. Em (52), (53) e (54), o Fenômeno "campanha", o Receptor "mensalão mineiro" e o Atributo "um tema que merece ...", são recursos utilizados pelo candidato para invalidar o posicionamento de DR.

Tendo em vista o exposto sobre o uso da transitividade no debate final dos presidenciáveis, apresentam-se algumas conclusões acerca das auto/representações realizadas pelos dois candidatos. 


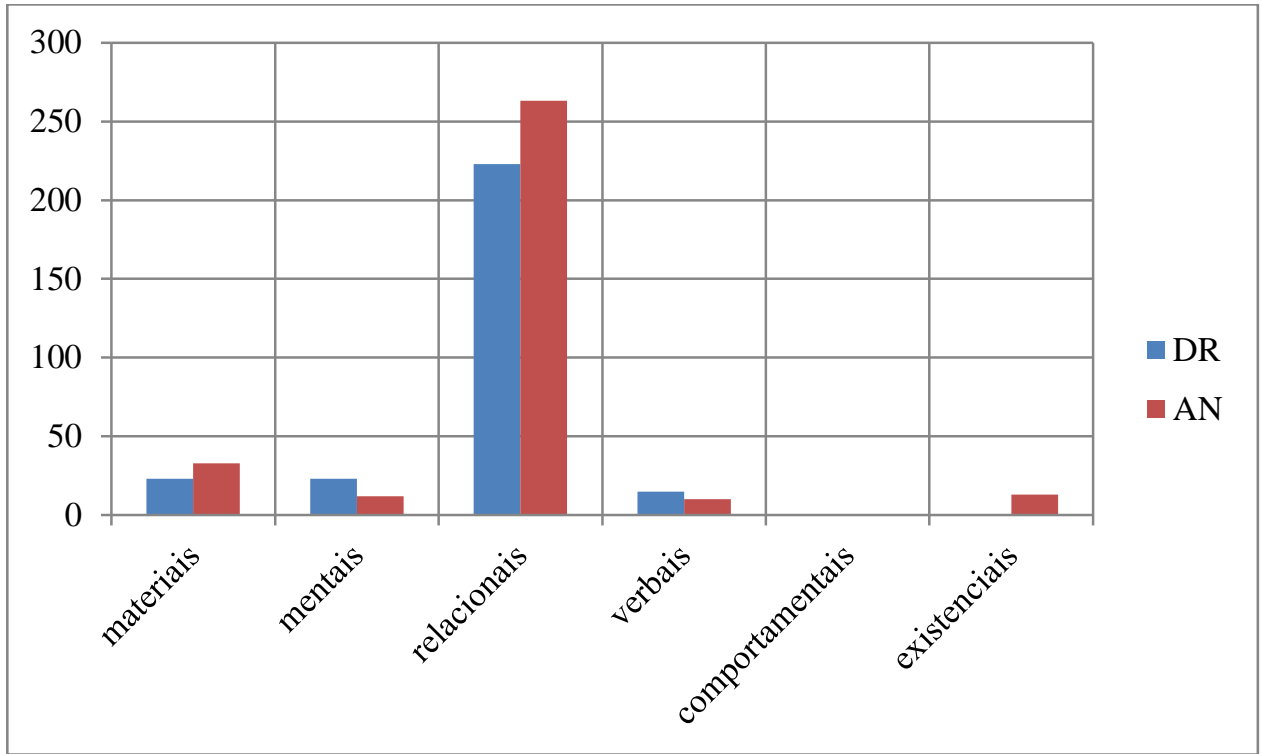

Figura 4: Quantitativo: processos no corpus (ponto de corte: $100^{\mathrm{a}}$ palavra)

A Figura 4 apresenta um comparativo, entre DR e AN, do emprego de processos utilizados no debate de 1h50min. Ambos os debatedores preferiram investir nos processos relacionais, mais do tipo Identificador que do tipo Atributivo. Os processos relacionais mais frequentes, no corpus, são "ser" e "ter". Os Identificados são “eu”, “o senhor/a senhora",

A justificativa para o grande número de processos relacionais diz respeito à necessidade dos candidatos em mostrarem sua identidade para os eleitores (eu sou x) e também para fazerem sobressair as diferenças entre um e outro.

Após os relacionais, os processos mais frequentes no corpus são os mentais, em que prevalecem "querer", “achar" e "acreditar", cujos Fenômenos ou projeções indicam atos de fala, bens materiais e imateriais. Destaque deve ser dado ao desiderativo "querer", geralmente acompanhado de relato com processo verbal (quero dizer/falar). No contexto do debate, é natural que os candidatos queiram dizer aos eleitores o que pretendem fazer quando no poder.

A representação do outro, por sua vez, ocorre com o emprego de processos materiais, mentais, relacionais e verbais. DR constrói AN como aquele que faz uma política equivocada, que precisa estudar mais para conhecer o funcionamento da máquina administrativa, que está errado em suas atitudes e que diz incoerências. O candidato opositor, por sua vez, constrói DR como alguém que, no poder, não realizara ações importantes para as mudanças desejadas no país, que se engana ao fazer julgamentos, que possuíra todas as condições materiais para promover o desenvolvimento no país e que faz pronunciamentos inadequados ao ofender o rival. 


\section{Considerações finais}

O discurso político, enquanto instância discursiva, tem, na manifestação de comportamentos linguísticos e de estruturas argumentativas, o objetivo de persuadir o eleitor a se manifestar nas urnas a favor de um ou de outro candidato. A persuasão, ingrediente fundamental para influenciar o eleitor, joga com estratégias e também com representações que precisam se impor diante de um grupo social.

Como foi mencionado inicialmente, a regulação do discurso político ocorre quando o outro também possui um projeto de influência, conforme Charaudeau (2011, p. 16). Uma característica importante do discurso político, segundo Pinto (2006), é a necessidade de sobrevivência e de imposição de sua verdade para um grande público.

Um debate, principalmente o último antes da decisão nas urnas, demonstra claramente que o discurso político é uma arena onde lutam opositores, tentando vencer ao imporem suas verdades. Por esse motivo, uma das estratégias utilizadas pelos contendores é a desqualificação do outro e de seu possível governo. Na análise acima apresentada, percebe-se que a representação que um contendor faz do outro caminha nessa direção.

As auto/representações construídas por DR e AN por ocasião do último debate de 2014 são elaboradas a fim de demonstrar a capacidade e o preparo de cada um para o exercício pleno da Presidência da República. A candidata, ao empregar processos relacionais, mentais desiderativos e mentais cognitivos, coloca-se como alguém que, por ter exercido já há quatro anos o cargo, conhece profundamente o sistema e que, por isso, é a candidata ideal. Por outro lado, AN autorrepresenta-se como o elemento da mudança capaz de modificar o futuro do país. Isso é passível de observação através do uso de processos relacionais e materiais no decorrer do texto.

Para a análise da batalha que se trava pela linguagem no campo político, o aparato teórico da Linguística Sistêmico-Funcional pode ajudar na sustentação de uma análise do discurso textualmente orientada e também para o desvelamento de identidades que são construídas para persuadir o eleitor e dele obter votos.

Os resultados aqui relatados não representam a interrupção do trabalho. Perspectivas futuras de análise do discurso político sob a ótica da ADC (Análise do Discurso Crítica), apoiada pela Linguística Sistêmico-Funcional (LSF), podem ser ainda mais reveladoras dessa prática discursiva. Outra possibilidade é a análise do papel da linguagem, sob o ponto de vista da metafunção interpessoal, no debate analisado neste artigo, ricamente constituída, tendo em 
vista a natureza da prática social em questão. Investigações dessa natureza podem também ser realizadas em outros exemplares de gêneros característicos da esfera política.

Recebido em: junho de 2015 Autora convidada para este volume

sara.scotta.cabral@gmail.com

\section{Referências bibliográficas}

AKEL, S. Presidenciáveis participam hoje de último debate. Estadão. 24.out.2014. Disponível em: <http://politica.estadao.com.br/noticias/geral,presidenciaveis-participam-hojede-ultimo-debate,1581951>. Acesso em 25.out.2014.

BLOOR, T; BLOOR, M. The functional analysis of English: a hallidayan approach. London: Edward Arnold, 1995.

BÜHLER, K. Sprachtheorie: Die Darstellungsfunktion der Sprache. 3 Auflage. Stuttgart: G. Fischer, 1999 [1934].

CHARAUDEAU, P. Discurso político. São Paulo: Editora Contexto, 2011.

CHILTON, P; SCHAFFNER, C. The role of misused concepts in manufacturing consent: a cognitive account. In: CHILTON, P; SCHAFFNER (ed.) Politics as tex and talk: analytic approaches to political discourse. Amsterdan: John Benjamins Company, 2002.

CONFRONTOS entre candidatos marcam debate tenso às vésperas do $1^{\circ}$ turno. Debate realizado pela TV Globo reuniu sete presidenciáveis no Rio. Disponível em: http://g1.globo.com/mundo/noticia/2014/10/voce-viu-o-ultimo-debate-dos-presidenciaveis-eoutras-noticias.html. Acesso em 05. out. 2014.

DE SOUZA, V. Power relations in Padre Cícero's epistolary political letters: an investigation in the light of systemic-functional grammar and critical discourse analysis. Tese (Doutorado em Letras). Universidade Federal de Santa Catarina, Florianópolis, 2011.

ELEIÇÕES 2014. Transcrição do debate da Globo. Disponível em: < http://g1.globo.com/politica/eleicoes/2014/transcricao-debate-presidencial-2-turno.html>. Acesso em 05.out.2014.

FUZER, C.; CABRAL, S. R. S. Introdução à gramática sistêmico-funcional em língua portuguesa. Campinas, SP: Mercado das Letras, 2014.

GOUVEIA, C. Texto e Gramática: uma introdução à linguística sistémico-funcional. Matraga, Rio de Janeiro, v. 16, n. 24, p.13-47, 2009.

HALLIDAY, M. A. K. An introduction to functional grammar. 2. ed. London: Routledge, 1994. 
HALliDAY, M. A. K.; MATTHIESSEN, C. M. I. M. Construing experience through meaning: a language-based approach to cognition. London and New York: Continuum, 1999.

. An introduction to functional grammar. 3. ed. London: Hodder Education, 2004.

. An introduction to functional grammar. 4. ed. London: Routledge, 2014.

HASAN, R. Part II. In: HALLIDAY, M. A. K.; HASAN, H. Language, context and text: aspects of a language in a social-semiotic perspective. Oxford: Oxford University Press, 1989.

LIMA, L. R. Processos existenciais em reportagens de capa da revista Superinteressante. Dissertação (Mestrado em Letras). Universidade Federal de Santa Maria, Santa Maria, 2013.

MALINOWSKI, B. A scientific theory of culture and other essays. Chapel Hill, N. Carolina: The University of North Carolina Press, 1944.

NEVES, M. H. de M. A gramática funcional. São Paulo: Martins Fontes, 1997.

PINTO, C. R. J. Elementos para uma análise de discurso político. Barbarói, Santa Cruz do Sul, v. 24, n. 1, p. 78-109, 2006.

SCOTT, M. Programa Word Smith 5.0. Oxford: Oxford University Press, 2008. 